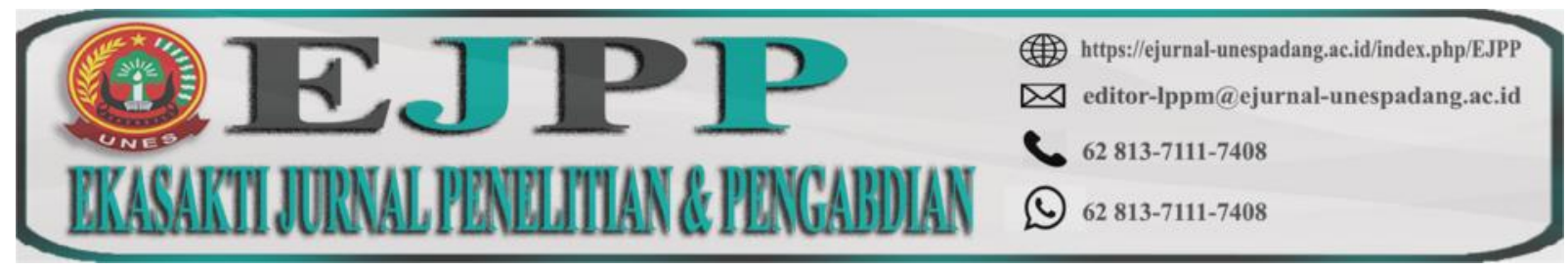

DOI: https://doi.org/10.31933/ejpp.v1i1

Received: 30/09/2020, Revised: 10/10/2020, Publish: 22/11/2020

\title{
TINJAUAN TERHADAP TRANSAKSI KONTRAK PERPINDAHAN PEMAIN SEPAK BOLA CLUB SEMEN PADANG F.C
}

\author{
Naldi Gantika ${ }^{1}$ dan Fahrul Yuwanda ${ }^{2}$ \\ ${ }^{1)}$ Fakultas Hukum Universitas Ekasakti Padang \\ E-mail: hgantika74@gmail.com \\ ${ }^{2)}$ Fakultas Hukum Universitas Ekasakti \\ E-mail: Fahrulyuwanda20@gmail.com
}

\begin{abstract}
ABSTRAK
Ketenaran sepakbola sudah tidak lagi hanya sebagai permainan atau olahraga fisik, tetapi sepakbola sudah menjadi bisnis yang menguntungkan bagi beberapa pihak. Tak terkecuali di Indonesia, kepopuleran dan keberadaan bisnis di dalamnya menjadikan olahraga kaki tersebut gencar di adakan di desa-desa, kota-kota dengan format turnamen-turnamen kampung atau yang lebih dikenal dengan istilah Tarkam sampai diadakannya kompetisi resmi di bawah PSSI yang diberi nama Liga 1. Profit yang menggiurkan bagi pihak yang berkecimpung di sepakbola menjadi salah satu dasar para pengusaha atau jutawan mendirikan akademi-akademi sepakbola usia dini, berinvestasi, dan mendirikan klub Profesional.
\end{abstract}

Kata Kunci: Transaksi Kontrak, Sepak Bola, Semen Padang FC.

\begin{abstract}
Football fame is no longer just a game or a physical sport, but football has become a profitable business for some. No exception in Indonesia, the popularity and existence of the business in it have made the foot sport intensively held in villages, cities with the format of village tournaments or better known as Tarkam until an official competition under the PSSI was called Liga 1. A tantalizing profit for those who are involved in football is one of the bases for entrepreneurs or millionaires to establish young football academies, invest, and establish professional clubs.
\end{abstract}

Keywords: Contract Transactions, Football, Cement Padang FC. 


\section{PENDAHULUAN}

Sepakbola merupakan salah satu olahraga yang paling digemari di seluruh dunia. Permainan kaki dengan tehnik mengolah bola dengan posisi berlari, menggoceknya hingga menendang masuk ke dalam gawang menjadi ciri khas permainannya. Sepakbola mampu menyatukan manusia dari segala golongan, budaya, ras dan agama sehingga dinobatkan sebagai salah satu olahraga pemersatu bangsa. Bahkan, di era ini sepakbola telah menjadi salah satu "simbol negara" sekaligus gambaran kekuatan Negara tersebut. Sebagaimana contoh Piala Dunia 2018 dimana timnas negara-negara yang lolos pada babak final akan saling berhadapan, saling mengeluarkan kekuatan terbaiknya, sampai saling mengalahkan agar nama negaranya menjadi yang terbaik di jagad ini.

Ketenaran sepakbola sudah tidak lagi hanya sebagai permainan atau olahraga fisik, tetapi sepakbola sudah menjadi bisnis yang menguntungkan bagi beberapa pihak. Tak terkecuali di Indonesia, kepopuleran dan keberadaan bisnis di dalamnya menjadikan olahraga kaki tersebut gencar adakan di desa-desa, kota-kota dengan format turnamen-turnamen kampung atau yang lebih dikenal dengan istilah Tarkam sampai diadakannya kompetisi resmi di bawah PSSI yang diberi nama Liga 1. Profit yang menggiurkan bagi pihak yang berkecimpung di sepakbola menjadi salah satu dasar para pengusaha atau jutawan mendirikan akademi-akademi sepakbola usia dini, berinvestasi, dan mendirikan klub Profesional.

Selama kompetisi berlangsung, bongkar pasang tim sudah lazim dilakukan oleh para klubklub elit di Negara Biru dengan tujuan menambah kekuatan dan kesolidan tim. Posisi penyerang dan gelandang serang bisa dikatakan sebagai ruh tim atau ruh permainan merupakan posisi yang paling sering dirombak. Daya gedor penyerang yang tajam dengan didukung gelandang serang yang mumpuni menjadikannya tim pembunuh dan ditakuti lawan. Kompetisi Liga 1 juga tidak lepas dari adanya perombakan-perombakan tim sebagaimana dilakukan oleh klub elit Eropa. Hal itu dapat di ketahui semakin ramainya klub-klub sepakbola Indonesia dalam melakukan jual beli atau biasa dinamakan transfer pemain. Transfer dilakukan guna mendapatkan pemain-pemain ternama dan berkualitas tinggi. Dalam pembelian seorang pemain bintang, manajemen klub pun tak tanggung-tanggung mengeluarkan dana yang fantastis agar pemain bersedia bermain membela klub tersebut, apalagi yang terjadi tiga tahun terakhir. Contoh misal Bali United yang berhasil memboyong dan mengontrak Lerby Eliandry Pong Babu dari Borneo FC senilai 4 Miliar pada tahun 2020. Nilai transfer ini termasuk nilai transfer mahal musim 2020. Adapun tujuan dari penelitian ini adalah: untuk mengetahui proses transaksi kontrak perpindahan pemain sepak bola club Semen Padang F.C dan Sanksi dan Berakhirnya Perjanjian Kontrak Pemain Sepak Bola Club Semen Padang F.C.

\section{METODE PENELITIAN}

Penelitian ini merupakan penelitian yuridis sosiologis, yaitu penelitian yang dilaksanakan dengan studi lapangan dan didukung dengan studi dokumen. Pendekatan yang digunakan dalam 
penelitian ini adalah pendekatan deskriptif analitis. Pengumpulan data penelitian yang dilakukan dalam penelitian ini menggunakan metode wawancara, observasi, dan telaah dokumen.

\section{HASIL DAN PEMBAHASAN}

\section{Proses Transaksi Kontrak Perpindahan Pemain Sepak Bola Club Semen Padang F.C}

Kesepakatan para pihak merupakan syarat sahnya perjanjian sebagaimana dalam Pasal 1320 KUH Perdata. Kata sepakat dari klub dan pemain terlepas dari adanya unsur paksaan maupun penipuan sehingga kata sepakat yang keluar merupakan kesepakatan yang hakiki, artinya pemain menghendaki terkait apa yang telah disepakatinya. Pemain diberikan hak untuk mengungkapkan kehendaknya ketika proses negosiasi berlangsung sehingga kedudukan menejemen dan pemain seimbang sebagaiman asas keadilan dan asas kesetaraan dan keseimbangan.

Selain kata sepakat terdapat syarat perjanjian yang lain yaitu para pihak merupakan subjek yang cakap hukum, artinya pemain telah dianggap dewasa dan tidak berada dalam pengampuan. Pemain-pemain Semen Padang FC merupakan pemain professional yang telah dinyatakan dewasa, Karena kebanyakan dari mereka sudah berumur di atas 21 tahun. Pemain yang masih berada di tim U-21 berhak promosi ke tim utama apabila permainan mereka sudah dianggap layak bermain di kompetisi tertinggi yaitu ISL. Pemain U-21 merupakan pemain yang berumur 19 tahun samapi umur 21 tahun dan berada satu tingkat di bawah tim utama. Hal ini sesuai dengan pasal $330 \mathrm{KUH}$ Perdata yang menyatakan seseorang telah dinyatakan dewasa jika telah berumur 21 tahun atau kurang dari 21 tahun tetapi sudah menikah. Selain itu Pasal 47 dan 50 UU No 1 tahun 1974 menyatakan kedewasaan seseorang ditentukan bahwa anak berada di bawah kekuasaan orang tua atau wali sampai dia berusia 18 tahun.

Perekrutan pemain yang dilakukan menejemen Semen Padang FC tidak hanya pada pemain lokal saja, melainkan mendatangkan pemain asing berkualitas. Bukan tanpa alasan Semen Padang FC merekrut pemain berkelas tersebut karena Semen Padang FC merupakan klub besar yang ada di Indonesia sehingga dengan diperkuat pemain tersebut mampu konsisten berada di jalur juara dan menjaga nama besar Semen Padang FC dan Kota Padang. Perjanjian tersebut mencerminkan tentang asas kebebasan berkontrak dan dengan asas ini setiap orang bebas melakukan perjanjian denga siapa dan apa saja saja sesuai dengan maksud dan keinginannya selama tidak bertentangan dengan Pasal 1320 tentang objek tertentu dan sebab yang halal.

Pada saat proses penandatanganan kontrak telah selesai, selanjutnya pemain akan melakukan prestasinya sebagai seorang pemain yaitu berlatih dan bermain pada seluruh pertandingan yang diikuti klub dengan sungguh-sungguh dan maksimal. Pemain diwajibkan untuk mentaati seluruh peraturan klub supaya performa pemain tetap terjaga dan terhindar dari sanksi. Adapun peraturan klub bervariasi tergantung kebijakan pelatih dan menejemen klub. Segala program latihan yang telah disusun dan seluruh instruksi pelatih merupakan kewajiban pemain yang harus diikuti selama perintah dan instruksi itu tidak bertentangan dengan Undang- 
undang karena pemain yang tidak mengikuti program tersebut terancam mendapat hukuman dan sanksi dari klub.

Disamping berkewajiban menaati seluruh peraturan klub, pemain juga bertanggung jawab terhadap kesehatan dan pola hidup pribadi supaya kebugaran pemain terhadap terjaga seperti memakan makanan yang hanya dikukus, olahraga pada waktu terjadinya jeda kompetisi sampai tidak meminum minuman beralkohol.

Pemain juga berhak untuk menolak dan tidak mengikuti kegiatan di luar sepakbola atau kegiatan yang bisa membahayakan keselamatan, seperti balap motor dan tinju. Selain bertanggung jawab secara pribadi terkait pemain professional pemain juga bertanggung jawab terhadap perilakunya dan menjaga nama baik klub, baik dalam lingkungan sosial, dalam latihan sampai ketika berada di lapangan pertandingan. Pemain wajib menghormati dan menerima seluruh keputusan wasit dan hakim garis ketika pertandingan berlangsung. Pemain yang protes secara berlebihan karena tidak menerima keputusan pengadil lapangan akan mendapat peringatan sampai diusir keluar, bahkan pemain yang memukul wasit akan mendapatkan sanksi dari LIGA.

Di luar program latihan, kegiatan resmi yang diadakan oleh klub harus diikuti oleh seluruh pemain. Pertemuan rutinan, kegiatan sosial seperti santunan terhadap anak yatim, coaching clinik pada sekolah sepakbola (SSB), laga persahabatan sampai kegiatan komersial yang diadakan oleh klub wajib dihadiri oleh pemain.

Berikut ini merupakan ketentuan mengenai kewajiban pemain, yaitu; Pasal 5 (lima).

1. Bermain maksimal (jika dimainkan) dalam pertandingan yang diikuti oleh klub.

2. Mengikuti seluruh pertandingan, program latihan, pertemuan tim, program persiapan pertandingan lainnya dan acara resmi klub berdasarkan instruksi dan perintah yang jelas dari pelatih kepala klub atau personil lain yang ditunjuk oleh klub.

3. Bertanggung jawab terhadap kesehatan pribadi, pola hidup dan kebugaran pribadi terkait dengan tugas dan tanggung jawab sebagai pemain profesional.

4. Mengikuti dan bertindak berdasarkan instruksi dan perintah dari ofisial klub selama perintah dan instruksi tersebut dapat diterima dengan alasan yang jelas.

5. Menghadiri kegiatan sosial dan komersial yang diselenggarakan oleh klub.

6. Mematuhi peraturan klub yang diberitahu sebelum penandatanganan kontrak, dengan catatan peraturan tersebut tidak bertentangan dengan Regulasi Sepakbola dalam perjanjian ini.

7. Menjaga tingkah laku pribadi dalam lingkup sportif terhadap orang lain di dalam pertandingan dan latihan, mempelajari dan menjalankan Laws Of The Game dan menerima seluruh keputusan wasit dalam pertandingan.

8. Menolak dan tidak mengikuti kegiatan lain di luar sepakbola atau kegiatan lain yang dapat membahayakan keselamatan atau kegiatan yang dilarang oleh klub.

9. Menjaga peralatan milik klub dan mengembalikan (apabila dipinjamkan) pada saat perjanjian berakhir.

10. Memberitahukan dengan segera kepada klub dalam hal terjadi sakit atau kecelakaan dan tidak diperbolehkan untuk melakukan tindakan medis dalam bentuk apapun 
sebelum memberitahukan kepada dokter klub (kecuali darurat) dan menyerahkan Data Medis kepada klub.

11. Menjalankan pemeriksaan medis dan perawatan medis berdasarkan permintaan dari dokter klub. Pemain memperoleh hak terhadap opini kedua dari seorang dokter independen ketika tidak setuju dengan opini dari dokter klub. jika masih terdapat perbedaan pendapat, para pihak setuju untuk menerima opini pihak ketiga yang independen yang sifatnya mengikat.

12. Menjalankan dan menghormati Statuta FIFA dan PSSI, Regulasi LIGA, PSSI, AFC, FIFA dan seluruh keputusan yang dibuat oleh FIFA, AFC, PSSI dan LIGA.

13. Tidak melakukan perbuatan yang mencemarkan nama baik klub.

14. Tidak melakukan perjudian atau tindakan judi yang berkaitan dengan sepakbola.

Dalam melaksanakan kewajiban sebagai seorang pemain professional, pemain juga berhak atas prestasi yang diperoleh dari klub. Klub wajib memenuhi prestasinya dalam hal kesejahteraan pemain selama pemain memperkuat klub tersebut. Kewajiban klub itu adalah tidak telat membayar gaji pemain setiap bulannya, menyediakan fasilitas kesejahteraan seperti tempat tinggal pemain, bonus penghargaan pemain, asuransi kesehatan dan pendapatan pemain ketika pemain tersebut cidera atau sakit yang diakibatkan membela klub. Klub juga berkewajiban menyediakan akomodasi, makanan, transportasi dan seluruh fasilitas dan peralatan yang dibutuhkan pemain ketika melaksanakan pertandingan. Selain itu, pemain juga berhak mendapatkan hari libur dan jaminan kesehatan dan bentuk perlindungan pemain.

Ketentuan terkait kewajiban klub di atas sesuai dengan; Pasal 6 (enam).

1. Melakukan kewajiban untuk kesejahteraan kepada pemain yang meliputi pendapatan pemain (uang kontrak dan gaji bulanan), fasilitas kesejahteraan pemain, bonus penghargaan pemain, ASKES dan pembayaran pendapatan saat pemain tidak bisa melakukan kewajiban karena sakit atau cidera yang dialami pemain karena bertanding atau hal lain karena instruksi atau perintah klub, Dana pensiunan dan JAMSOS merujuk kepada Hukum Ketenagakerjaan Negara Republik Indonesia, serta menggangti biaya yang dikeluarkan pemain terhadap keperluan atau kepentingan klub yang telah disepakti para pihak ( contoh; KITAS, tiket pesawat, dan lain-lain).

2. Menyediakan seluruh fasilitas dan peralatan yang diperlukan pemain sehubungan dengan pertandingan yang diikuti oleh klub (contoh: akomodasi, makanan, transportasi dan lain-lain).

3. Memberikan jaminan kesehatan dalam bentuk asuransi atau bentuk perlindungan lain kepada pemain.

4. Memberikan hak kepada pemain sehubungan dengan hari libur klub maupun hari libur resmi yang disepakiti oleh para pihak.

5. Memberikan perlindungan terhadap hak asasi dan non-diskriminasi pemain.

6. Melepas pemain yang secara resmi dipanggil oleh Tim Nasional untuk mengikuti pertandingan dimana ketentuan pelepasan pemain mengacu kepada regulasi FIFA. 
7. Menjalankan dan menghormati Statuta, Regulasi termasuk Kode Etik dan keputusan dari FIFA,AFC, PSSI, dan LIGA.

Segala kewajiban pemain dan klub merupakan bentuk dari sesuatu hal dalam kontrak sebagaimana syarat sah perjanjian. Sesuatu hal bisa saja berupa hak, jasa, benda atau sesuatu, baik yang sudah ada ataupun belum ada, asalkan dapat ditentukan jenisnya. Jenis dari perjanjian di atas adalah jasa, klub mengontrak pemain sepakbola untuk dimanfaatkan jasanya untuk membantu memperkuat klub supaya menjadi klub yang tangguh dan kuat. Prestasi-prestasi di atas tidak bertentangan dengan kesusilaan dan ketertiban umum sehingga jenis prestasi tersebut menjadi halal, karena tidak bisa dihindari bahwa syarat sahnya perjanjian adalah adanya sebab yang halal.

Unsur esensialia merupaka unsur yang harus ada dalam perjanjian karena unsur tersebut harus tertara dalam perjanjian. Unsur esensialia berbentuk ketentuan- ketentuan berupa kewajiban maupun hak yang harus dilakukan oleh pemain dan klub. selain terdapat unsur esensialia kewaiban pemain ini juga mencerminkan adanya unsur naturalia, yaitu unsur yang pasti ada dalam perjanian meskipun Undang-undang tidak mengaturnya. Seperti menyediakan makanan yang halal oleh klub terhadap pemain muslim ketika pemain sedang mengikuti pertandingan. Kehendak para pihak untuk saling melaksanakan prestasi merupakan asas iktikad baik para pihak sebagaimana Pasal 1338 ayat (3) yang menyebutkan bahwa "Perjanjianperjanjian harus dilaksanakan dengan itikad baik." Ketentuan ini mempertegas perjanjian yang dilakukan para pihak, karena prestasi yang dilakukan oleh salah satu pihak tidak menggugurkan prestasi pihak lain. Sehingga tanpa adanya iktikad baik, pihak yang lain bisa saja meninggalkan prestasinya. Kesepakatan prestasi yang telah dibuat dan disepakati para pihak mempunyai kekuatan mengikat bagi meraka, hal ini sebagaimana asas facta sunt servanda dalam Pasal 1338 ayat (1) KUH Perdata. Semua perjanjian memiliki asas kekuatan mengikat terhadap pihak pihak dalam perjanjian yakni sebagaimana disebutkan di dalam pasal tersebut "berlaku sebagai undang-undang bagi mereka yang membuatnya."

\section{Sanksi dan Berakhirnya Perjanjian Kontrak Pemain Sepak Bola Club Semen Padang F.C}

Pemain yang dipercaya untuk bermain merupakan pemain yang dalam kondisi bugar dan sehat. Pemain yang sedang cidera akan mendapatkan perawatan khusus dari dokter tim sampai pemain tersebut kembali pulih dan siap bermain. Dalam mengikuti pertandingan, pemain dilarang menggunakan obat-obatan yang berimplikasi menjadikan kuat meskipun pemain tersebut kelihatan sehat. Penggunaan obat-obatan peningkat performa atau yang dikenal dengan doping sangat dilarang oleh semua regulasi kususnya sepakbola dengan alasan akan dampak negatif bagi kesehatan atlit. Pemain yang terbukti menggunakan doping akan mendapatkan sanksi tegas dari Komisi Disiplin PSSI maupun badan yang berwenang. Pemain yang terbukti doping dengan kadar tinggi dapat diberikan sanksi berupa larangan berkecimpung di dunia sepakbola seumur hidup. Untuk itu, bagi para pemain yang sedang mengalami masalah kebugaran maupun cidera selama penyembuhan berlangsung dianjurkan untuk mengontrol obatobat yang diberikan tim medis maupun dokter tim supaya terhindar dari kasus doping tersebut. 
Selain obat, bentuk lain dari doping adalah doping darah yang disalurkan melalui transfusi darah atau penggunaan hormon.

Ketentuan mengenai larangan doping diatur dalam pasal sebagai berikut; Pasal 10 (sepuluh):

1. Para pihak sepakat untuk menghormati regulasi tentang doping yang berlaku.

2. Doping dilarang dan seluruh pihak yang terbukti terlibat dalam pelanggaran terhadap regulasi tentang doping akan dikenakan sanksi oleh Komisi Disiplin PSSI atau badan lain yang berwenang untuk menjatuhkan hukuman.

3. Klub berhak untuk melakukan pemeriksaan terhadap pemain yang terbukti bersalah menggunkaan doping.

4. Pemain berhak untuk mengotorisasi pemberian obat-obatan yang dilakukan oleh dokter tim atau staf medis klub.

Perjanjian kontrak pemain berakhir setelah jangka waktu kesepakatan tersebut telah selesai atau adanya kesepakatan tertulis antara pihak pemain dan klub. Pemain segera mencari klub baru untuk berlabuh setelah masa perjanjiannya tidak diperpanjang oleh klub yang lama. Kontrak yang telah disepakati oleh pemain dan klub tidak dapat diakhiri pada saat berjalannya kompetisi. Namun pada berjalannya waktu, hubungan pemain dan klub juga mengalami permasalahan. Misalnya pemain sering tidak tepat waktu latihan dan melanggar peraturan klub yang berimplikasi pemain tidak betah. Tidak semua pemain mempunyai sifat sama antara satu dengan yang lain, hal itu terlihat ketika bertanding di lapangan. Beberapa sifat pemaian antara lain adalah sering emosi, ada pemain yang sabar, keras, dan lugu. Sifat tersebut juga dibawa ke luar lapangan, bahkan tidak sedikit pemain yang mealkukan perbuatan pidana akibat mabuk maupun memakai narkoba. Pemalsuan terhadap data-data pribadi sangat sering kita temukan pada kasuskasus sepakbola seperti pemalsuan usia. Dalam hal ini, Klub berhak untuk mengakhiri perjanjian secara sepihak dengan konsekuensi biaya yang telah dikeluarkan klub dikembalikan secara penuh. Pemain yang terbukti menerima suap agar timnya mengalah juga tidak terlepas dari pengakhiran sepihak oleh klub.

Pada sebuah klub sepakbola, jumlah pemain kurang lebih berjumlah 26 (dua piluh enam)30 (tiga puluh) pemain dan dari jumlah tersebut semuanya akan bersaing untuk mendapatkan posisi di tim utama. Pemain yang mendapatkan tim utama merupakan pemain yang mempunyai permainan terbaik diantara para pemain lainnya, sehingga tidak sedikit pemain yang menjadi pelapis dan menghuni cadangan. Dalam hal ini, pemain berhak untuk melakukan pengakhiran kontrak secara sepihak apabila pemain hanya bermain kurang dari 10\% (sepuluh persen) dari jumlah total pertandingan resmi yang dilakukan oleh klub.

Ketentuan pengakhiran kontrak ini adalah sebagai berikut; Pasal 11 (sebelas).

1. Perjanjian ini hanya dapat diakhiri karena berakhir sesuai dengan jangka waktu perjanjian atau karena diakhiri berdasarkan kesepakatan tertulis dari para pihak, dan kesepakatan tertulis tersebut ditembuskan/diketahui terhadap LIGA.

2. Dengan ditandatanganinya perjanjian ini, maka kesepakatan atau perjanjian yang pernah dibuat sebelumnya adalah batal demi hukum. 
3. Perjanjian ini dapat diakhiri oleh klub dengan konsekuensi dikembalikan seluruh biaya yang telah dikeluarkan oleh klub berdasarkan perjanjian ini, apabila pemain melakukan hal-hal di bawah ini;

a. Terbukti melakukan perbuatan pidana berdasarkan kaidah hukum yang berlaku.

b. Terbukti memalsukan pernyataan, dokumen atau data-data diri yang berhubungan dengan pihak ketiga atau lainnya.

c. Terbukti menerima suap berdasarkan bukti/saksi yang diperoleh.

4. Pemain dapat melakukan pengakhiran perjanjian secara sepihak karena alasan Just Sporting Cause yaitu jumlah pertandingan dimana pemain bermain kurang dari $10 \%$ (sepuluh persen) dari total jumlah pertandingan resmi yang telah dilakukan oleh klub.

5. Pemain tidak dapat melakukan pengakhiran perjanjian berdasarkan ayat (d) di atas hingga 15 (lima belas) hari setelah pertandingan resmi terakhir yang dilakukan oleh klub pada musim kompetisi atau turnamen yang berjalan.

6. Pelaksanaan terhadap ayat (d) dan (e) di atas hanya berlaku terhadap pemain dengan durasi kontrak lebih dari satu musim.

7. Perjanjian ini tidak dapat diakhiri pada saat berjalannya musim kompetisi atau turnamen yang sedang berjalan, kecuali terjadi situasi sesuai dengan ayat (a), (b), (c), dan (d) di atas.

8. Ketentuan tentang pengakhiran perjanjian ini mengacu kepada regulasi FIFA.

9. Tidak satupun dalam pasal ini yang dapat memberikan hak kepada klub untuk memutuskan perjanjian ini yang berlawanan dengan Hukum Ketenagakerjaan Negara Republik Indonesia.

Pelaksanaan prestasi antara pemain dan klub tidak selalu berjalan dengan lancar. Kewajiban kedua belah pihak seakan merupakan satu kesatuan yang tidak bisa dipisahkan. perkara yang sering terjadi dalam persepakbolaan adalah penunggakan gaji oleh klub sampai berbulan-bulan, sehingga banyak pemain yang mempunyai usaha sampingan demi menghidupi keluarganya. Apabila terjadi perselisihan maupun persengketaan antara klub dan pemain maka penyelesaian yang digunakan oleh dua belah pihak adalah jalan musyawarah dan mufakad. Dengan jalan musyawarah, klub dan pemain diharapkan menemukan solusi yang saling menguntungkan. Namun, apabila kedua belah pihak tidak mencapai kata sepakat terhadap penyelesaian dengan cara musyawarah, maka jalan penyelesaian yang harus dilalui kedua belah pihak adalah mengadu ke Pengadilan Ketenagakerjaan atau melalui lembaga penyelesaian sengketa (National Dispute Resolution Chamber).

Ketentuan mengenai penyelesaian keluhan adalah sebagai berikut: Pasal 12 (dua belas)

1. Dalam hal terjadinya sebuah keluhan, pemain dan klub hendaknya berusaha untuk menyelesaikannya dengan jalan musyawarah dan mufakat.

2. Apabila pemain dan klub tidak mampu untuk menyelesaikan keluhan, mempertimbnagkan keadilan bagi pemain dan klub, keduanya diminta untuk mengadu permasalahan kepada Pengadilan Ketenagakerjaan atau kedua belah pihak dapat 
menyerahkan keluhan kepada penyelesaian yang dapat dicapai melalui National Dispute Resolution Chamber.

Pengakhiran perjanjian hanya dapat dilakukan apabila terdapat kesepakatan tertulis para pihak selain itu masa perjanjian tersebut telah habis atau telah lewat masa perjanjian. Hal ini sesuai dengan pasal Pasal 1946 KUH Perdata yang menyatakan lewat waktu ialah suatu upaya untuk memperoleh sesuatu atau untuk dibebaskan dari suatu perikatan. Dengan demikian maka perjanjian yang telah lewat masa secara otomatis berakhir juga perikatan antara klub dan pemain. Selain karena sebab lewat waktu, perjanjian juga dapat berakhir karena adanya syarat. Perikatan yang bersyarat adalah suatu perikatan yang digantungkan pada suatu peristiwa yang masih akan datang dan masih belum tentu akan terjadi..

\section{KESIMPULAN}

Proses Transaksi Kontrak Perpindahan Pemain Sepak Bola Club Semen Padang F.C Ketentuan kesepakatan jangka waktu perjanjian di atas sesuai Pasal 3 (tiga): 1) Masa perjanjian yang dilakukan oleh para pihak adalah 1 (satu) tahun kompetisi, dan tiap tahun kompetisi berumur 12 (dua belas bulan), 2) Antara 2 (dua) sampai 6 (enam) bulan menjelang berakhirnya perjanjian ini, para pihak sudah wajib bersepakat tentang status perjanjian terkait dengan perpanjangan atau pengakhiran dan dilaporkan statusnya secara tertulis kepada LIGA. 3) Mengacu pada paragraf 2 (dua) dalam pasal ini, pemain dapat melakukan negosiasi dan memulai perjanjian kerja dengan klub lain apabila kontraknya telah habis masa atau akan habis dalam jangka waktu kurang dari 6 (Bulan) dan Pasal 4 (empat) tentang nilai dasar perjanjian dan metode pembayaran. Ketentuan pengakhiran kontrak ini adalah sebagai berikut; 1) Perjanjian ini hanya dapat diakhiri karena berakhir sesuai dengan jangka waktu perjanjian atau karena diakhiri berdasarkan kesepakatan tertulis dari para pihak, dan kesepakatan tertulis tersebut diketahui terhadap LIGA, 2) Dengan ditandatanganinya perjanjian ini, maka kesepakatan atau perjanjian yang pernah dibuat sebelumnya adalah batal demi hukum, 3) Perjanjian ini dapat diakhiri oleh klub dengan konsekuensi dikembalikan seluruh biaya yang telah dikeluarkan oleh klub, 4) Pemain dapat melakukan pengakhiran perjanjian secara sepihak karena alasan Just Sporting Cause, 6) Pelaksanaan terhadap ayat (d) dan (e) di atas hanya berlaku terhadap pemain dengan durasi kontrak lebih dari satu musim, 7) Perjanjian ini tidak dapat diakhiri pada saat berjalannya musim kompetisi atau turnamen yang sedang berjalan, kecuali terjadi situasi sesuai dengan ayat (a), (b), (c), dan (d) di atas, 8) Ketentuan tentang pengakhiran perjanjian ini mengacu kepada regulasi FIFA dan 9) Tidak satupun dalam pasal ini yang dapat memberikan hak kepada klub untuk memutuskan perjanjian ini yang berlawanan dengan Hukum Ketenagakerjaan Negara Republik Indonesia..

\section{REFERENSI}

Abdul Rohim, Dasar-Dasar Sepak Bola. Aneka Ilmu, Demak, 2008,

Abdulkadir Muhammad, Hukum Perjanjian, Citra Aditya Bakti, Jakarta,1986, 
Chairun Pasribu, Suharawardi Lubis, Hukum Perjanjian dalam Islam, Jakarta, 2011,

Eko Noer Kristiyanto, Implementasi Peraturan Menteri Dalam Negeri Nomor 13 Tahun 2006 Tentang Pendoman Pengelolaan Keuangan Daerah Dalam Pengalokasian Dana APBD Kepada Klub Sepak Bola Peserta Liga Indonesia, UNPAD, Bandung, 2008,

Hilda IP Pandjaitan, Kedaulatan Negara VS Kedaulatan FIFA, PT. Gramedia Pustaka Utama, Jakarta, 2011,

J. Satrio, Hukum Perjanjian, Citra Aditya Bakti, Bandung, 1992,

R. Soeroso, Perjanjian di Bawah Tangan (Pedoman Pembuatan dan Aplikasi Hukum), Alumni Bandung, Bandung, 1999,

Remmy Muchtar. Olahraga Pilihan Sepakbola. Depdikbud. Dirjendikti. 1992,

Ridwan Khairandy, Iktikad Baik dalam Kebebasan Berkontrak, Program Pascasarjana Fakultas Hukum Universitas Indonesia, Jakarta, 2004,

Salim MS, Hukum Kontrak, Teori \& Teknik Penyusunan Kontrak, Sinar Grafika, Jakarta, 2008.

Setiawan, Aneka Masalah Hukum dan Hukum Acara Perdata, Alumni, Bandung, 1992,

Subekti, Hukum Perjanjian, Cet. XVI, Intermasa, Jakarta, 1996,

Subekti, Hukum Perjanjian, PT Inermasa, Jakarta, 1987,

Tood D. Rakoff, Contract of Adhesion an Essay Inreccontruction, 1983,

Undang-undang Dasar Negara Republik Indonesia Tahun 1945;

Kitab Undang-undang Hukum Perdata (KUHPerdata).

Undang-Undang Republik Indonesia Nomor 3 Tahun 2005 tentang Keolahragaan Nasional.

Peraturan Pemerintah Nomor 16 Tahun 2007 tentang penyelenggaraan Keolahragaan. 